\title{
AS POSSIBILIDADES DE CONSTRUÇÃO DO(S) SENTIDO(S): DA FÔRMA-LEITOR À FUNÇÃO-LEITOR
}

\section{Leda Verdiani Tfouni ${ }^{(*)}$ Soraya Maria Romano Pacífico ${ }^{(* *)}$}

Resumo: Este artigo pretende discutir como as atividades de leitura podem contribuir com a construção dos sentidos dos textos, criticando, de acordo com os pressupostos teóricos da Análise de Discurso de 'linha'francesa', a concepção de leitura única. Entendemos interpretação como a possibilidade de o sujeito compreender que o sentido pode ser outro, mas não qualquer um, pois para nós interpretar é compreender que a ideologia faz parecer naturais determinados sentidos e não outros e, quando o leitor chega à interpretação ele assume o que denominamos função-leitor. Ao assumir a função-leitor, o sujeito não repete os sentidos instituídos como dominantes e, sim, procura investigar como se dá, num dado momento sócio-histórico, o funcionamento discursivo, que é novo e único em cada texto. Por outro lado, a fôrma-leitor está relacionada à interdição do sujeito ao interdiscurso, o que equivale a dizer que o leitor não consegue se inserir no processo sócio-histórico de construção de sentidos e, por isso, ele tem a ilusão de que cada palavra tem um sentido único. A partir de análises de redações de alunos do curso de Psicologia de uma universidade particular de Ribeirão Preto-SP, consideramos que as atividades de leitura realizadas na escola, principalmente aquelas pautadas na repetição do sentido legitimado pelo livro didático, levam o sujeito a assumir a fôrma-leitor e, diante disso, julgamos fundamental que o trabalho escolar aconteça não pela imposição de um sentido, mas sim, possibilitando ao sujeito estar em contato e em confronto com as várias possibilidades de leitura dos textos.

Palavras-chave: Leitura; interpretação; ideologia; fôrma-leitor; funçãoleitor

(*) Professora Associada do Departamento de Psicologia e Educação da FFCLRP- Universidade de São Paulo.

("*) Professora Doutora do Departamento de Psicologia e Educação da FFCLRP- Universidade de São Paulo. 
“...para que a manhã, desde uma teia tênue, / se vá tecendo, entre todos os galos".

João Cabral de Melo Neto

Iniciamos afirmando que é impossível falar em sentido sem considerar a interpretação.

Sabemos que todo sujeito está fadado a interpretar. Ou melhor, podemos afirmar que onde existe sujeito, existe interpretação.

Embora a interpretação linguajeira (interpretação cotidiana da linguagem, sem embasamento teórico) acompanhe o homem em todas as suas atividades, percebemos, na atividade docente, que os alunos apresentam uma forte resistência e, muitas vezes, insegurança para realizar as tarefas relacionadas à leitura e interpretação, no contexto escolar, talvez porque nesse contexto tem-se a ilusão de que a interpretação precisa ser baseada em aparato teórico ( o qual, na maioria das vezes, não é o mais adequado, ou, outras vezes, nem existe).

Essa resistência ou insegurança do aluno nos causam um desconforto, pois sabemos que toda vez que o sujeito deixa de ler ou de interpretar, "alguém" o faz por ele, ou indo além, considerando a relação desigual de poder que bloqueia o acesso do sujeito às atividades de escrita, podemos dizer que, mesmo quando o sujeito está disposto a ler e a interpretar, o sentido já está determinado antes, pelas instituições, e, sendo a escola a instituição encarregada de fazer valer os valores da classe dominante, o sujeito aí inserido é levado a "descobrir" o que o texto "quer dizer" (o sentido permitido, nãoperigoso); qual a "intenção" do autor do texto; sua única interpretação possível (interpretação eleita pelo livro didático), como se houvesse a possibilidade de penetrar no pensamento do outro para desvendar as intenções significativas que subjazem ao texto.

Pretendemos mostrar aqui que esse tipo de atividade de leitura faz com que se apaguem as várias possibilidades de interpretação que os textos oferecem, o que leva o leitor a assumir, como veremos, a fôrma-leitor.

Essa concepção de leitura única fundamenta-se na visão de transparência da linguagem, isto é, nas teorias da comunicação e ciências positivistas e pressupõe uma relação direta entre pensamento 
e linguagem, como se um emissor qualquer enviasse uma mensagem para um receptor qualquer, mensagem esta que refletiria o pensamento do emissor e deveria ser decodificada perfeitamente pelo receptor, ou seja, numa concepção segundo a qual tudo que é dito deveria ser entendido por todos, da mesma maneira.

Concepções como esta escamoteiam a heterogeneidade do sujeito, da linguagem, do contexto e, principalmente, que a interpretação é um fato ideológico e que a sociedade não é igualitária, o que nega a concepção universalista de sujeito que circula na instituição escolar.

Situando-nos no referencial teórico da Análise do Discurso de filiação francesa (AD), concebemos que interpretar significa atribuir sentidos aos textos, considerando as condições em que eles foram produzidos. Partindo disto, queremos discutir que, para a AD, a interpretação não é entendida tal como propõe a definição do código da língua portuguesa (interpretar é esclarecer, explicar o sentido de), e vale dizer que tal definição é legitimada pelo livro didático. Isto se justifica, em primeiro lugar, pelo fato de que a $\mathrm{AD}$ não trabalha com os significados dados pelo código e, em segundo lugar, porque a definição do código pressupõe a necessidade de um "esclarecimento", o que implica considerar a transparência, a clareza da linguagem, concepção criticada pela AD.

Além disso, considerando o conceito de interpretação tal como proposto no código, somos levados a pensar que todo sujeito que se depara, por exemplo, com a palavra "cachorro", atribuirá o mesmo significado para este significante, o que sugere um apagamento da constituição histórica do sujeito e do sentido, pois trabalhar com o conceito de interpretação como algo que está pronto para ser percebido por um sujeito é o mesmo que partir do pressuposto de que há uma homogeneização dos sujeitos, dito de outra maneira, pressuposto de que todos os sujeitos ocupam as mesmas posições sócio-histórico-ideológicas para interpretar as palavras, os textos.

Encontramos em Tfouni (no prelo) uma análise muito interessante, que coincidentemente toma por objeto o significante "cachorro", apontando sua polissemia acerca disso.

Tfouni analisa um recorte de uma entrevista com uma mulher grávida, entrevista esta que foi realizada na cozinha da casa da entrevistada, que era em frente a um corredor, onde estava preso um 
cachorro, que tentava a todo momento entrar, mas não podia, pois havia um portãozinho impedindo a passagem. Em um dado momento, o seguinte diálogo ocorreu entre essa mulher (S) e a entrevistadora (E):

E: Vem cá, você conversa sobre o nenê com outras pessoas?

S: Assim, com a família eu não converso, não.

E: Por quê?

$\mathrm{S}$ : Com o marido também não. Ah, porque eles são muito agressivo; sabe, eles não te dão uma chance pra você falá o que você qué; eles acham que você só tem que ouvi, entende? Que nem hoje cedo; eu falei pro meu marido: "eu tô entrando no sexto mês e não parei de trabalhar, sendo que a médica já me afastou". Aí, ele virou pra mim gritou e falou assim: "É? Você qué o quê? Você não come? Você vai trabaia até o dia de tế; a minha mãe trabaiô na roça e teve nóis no meio do pé de café". Bom, aí já fiquei sabe... Olha o cachorro!"

Tfouni (no prelo), indaga "como deve ser entendido aí o enunciado "Olha o cachorro"? Qual o sentido de "cachorro" aí? Do ponto de vista de uma seqüência formal, poderíamos dizer que "o cachorro", no enunciado, refere-se ao cachorro que está latindo no corredor, uma vez que o sujeito, na situação de diálogo está nomeando ostensivamente um referente do "mundo real" para seu interlocutor. Porém, se perseguirmos o fio significativo do discurso, a forma como o marido está sendo apresentado discursivamente pelo sujeito, através de significantes "agressivo", "não dá uma chance pra você falá", "gritou", "você não come?", cabe também a interpretação segundo a qual o "cachorro" é a metáfora do "marido". Maneira deslocada de referir-se, só possível pelo caráter de equivocidade da língua, advindo do fato de que os significados não aderem permanentemente aos significantes".

Dessa forma, e ainda de acordo com a autora, "vemos a memória se atualizando em acontecimento, permitindo ao sujeito falar de sua dor, de seus medos, suas angústias, de maneira deslocada, sem se dar conta do verdadeiro efeito de sentido que está produzindo".

Isso significa que, para a autora, assim como para a $\mathrm{AD}$, a memória, o "já-lá" sustenta a construção de sentidos, visto que as palavras não têm sentidos em si, pois não há o sentido único, mas sim, 
uma teia sócio-histórica que possibilita a construção de intradiscursos e sua relação com o interdiscurso.

Continuando nossa argumentação contra a leitura literal, contra a concepção de sentido único, questionamos como ficaria a interpretação do seguinte enunciado? "Ela é pobre, mas é limpinha." É possível afirmar que existe apenas uma maneira de se interpretá-lo? Quais são os sentidos possíveis para a palavra "limpinha"? É possível interpretá-la apenas como alguma coisa ou pessoa sem sujeira, sem mancha, ou talvez, pura, transparente?

No enunciado acima, é a presença do conectivo "mas" que nos leva a investigar os sentidos possíveis para a palavra "limpinha". Concordamos com Maingueneau (1993) em que a análise deste conectivo é muito interessante para a $\mathrm{AD}$, dada a sua freqüência e a sua ligação com o implícito. Assim, para compreender os sentidos de "limpinha" é preciso levar em conta a existência da ideologia, que faz parecer "natural" que este enunciado circule, amplamente, em nossa sociedade; considerar os conteúdos implícitos, enfim, considerar que os sentidos dos textos extrapolam, vão além do literal, do significado dado pelo dicionário.

No exemplo acima, a palavra "limpinha" poderia ser considerada como um atributo do sujeito, até um elogio, talvez, se fosse interpretada fora do discurso; porém, no intradiscurso seu uso cria um efeito de sentido de aviltamento, uma vez que estabelece uma relação (ideológica) entre pobreza e sujeira, relação possível de ser compreendida pela marca do conectivo interfrástico "mas", que sugere que, neste caso, o sujeito, apesar de ser pobre, não é sujo, ou, dito de outra forma, "é limpinha". Esta leitura justifica-se, também, pelo uso do diminutivo "limpinha", pois sabemos que a presença do diminutivo, nos textos, pode criar tanto um efeito de sentido pejorativo, de rebaixamento, quanto um efeito de sentido de afetividade, sendo que este, para nós, não é o sentido dominante neste enunciado, visto que em nossa sociedade circulam (ideologicamente) sentidos construídos historicamente, que relacionam pobreza à sujeira, à feiúra, à marginalidade, à inferioridade, etc, sentidos estes recuperados pela memória, pelo já-lá. Daí, nossa interpretação do sentido dominante para "limpinha", nesse uso.

Por outro lado, enunciados como "ela é rica, mas é limpinha" não circulam em nossa sociedade, pois parece "natural" que o rico seja 
limpo. Neste caso, o uso do conectivo "mas" não possibilita a oposição à interpretação argumentativa que é construída entre "rica" e "limpinha", visto que, historicamente foram construídos sentidos (interdiscursos) que relacionam riqueza à beleza, à limpeza, ao poder, à superioridade.

Ducrot (1972), entre outros autores, critica esta visão de que os conteúdos são explicitamente ditos e mostra que há conteúdos implícitos, isto é, junto com um dizer existe, também, a possibilidade de um não-dizer que também significa, e a compreensão desse nãodito acontece a partir de marcas lingüísticas presentes nos enunciados (o que Ducrot chama de pressuposto) ou (e, também) a partir da relação do enunciado com a enunciação (o que o autor chama de subentendido).

Essa discussão é relevante, uma vez que toda atividade de leitura (no sentido em que a entendemos, como interpretação, construção de sentidos), deve considerar e trabalhar com os conteúdos implícitos nos textos, fazendo o sujeito buscar compreender que todo dizer comporta também um nível de não-dito.

Para a análise do discurso, as marcas que possibilitam a relação do sujeito com a linguagem não são compreendidas mecanicamente, pois são construções ideológicas e produtos da história, e para compreendê-las é preciso investigar o funcionamento discursivo e a relação com o interdiscurso, ou a memória do dizer. Isso implica considerar uma dimensão de historicidade para os fatos de linguagem.

Assim, o trabalho com a interpretação passou a ser concebido como algo muito mais complexo do que a visão simplista de entendêla como explicação de um sentido a fim de torná-lo "claro", visão esta aceita e trabalhada na escola, conforme mostraremos, mais adiante.

Muitos autores têm atribuído um lugar especial à leitura e à interpretação, dentro dos estudos lingüísticos. Orlandi (1993), por exemplo, aponta três relações do sujeito com a significação. Partindo dos estudos de Halliday (1976) e transpondo-os para a análise do discurso, a autora sugere a distinção entre inteligível, interpretável e compreensivel. Tal distinção, como diz Orlandi (1993, p. 115), “... se organiza em torno da questão do assujeitamento e põe em foco a relação entre individuação e individualidade, entre enunciação 
(formulação) e enunciado (constituição), entre pontos de entrada e pontos de fuga".

Pode-se deduzir que, para a autora, existe uma hierarquia no processo de construção do sentido, isto é, todos os textos apresentam a possibilidade de ser inteligíveis, quer dizer, diante de um enunciado que apresente coesão (ligação entre as palavras), mesmo sem apresentar coerência interna (relação harmônica de sentido, encadeamento de idéias), o sujeito pode atribuir-lhe um sentido.

Como exemplo, podemos citar: "João venceu Lucas no jogo de xadrez". Embora sem saber quem são João e Lucas e sem conhecer as regras do jogo de xadrez, o sujeito pode atribuir um sentido restrito (decodificação) para o enunciado.

Por outro lado, se o sujeito conhecer os mecanismos lingüísticos de coesão, o enunciado pode ser interpretável. Para Orlandi (op. cit, p.115), " o interpretável é a que se atribui sentido levando-se em conta o contexto lingüístico (coesão)". Até aqui, estamos no nível do texto, estabelecendo a relação entre coesão e coerência internas ao texto.

Mas pensando nos estudos do discurso e, segundo a autora, há a necessidade de buscar a compreensão, que para Orlandi (op.cit.) está relacionada à exterioridade, à coerência externa do texto. Nas palavras da autora: “... o compreensível é a atribuição de sentidos considerando o processo de significação no contexto de situação, colocando-se em relação enunciado/enunciação".

Deste modo, no exemplo acima, para que haja a compreensão, faz-se necessário, além do inteligível e do interpretável, que o sujeito considere o interdiscurso (o já-lá) sobre o jogo de xadrez, o que pode significar (por exemplo, intelectualmente, numa relação de "poder") que João tenha vencido e Lucas perdido, ou seja, quais são os sentidos que estão além da decodificação.

De acordo com Orlandi (1993, p. 115):

A compreensão se instaura no reconhecimento de que o sentido é sócio-historicamente determinado e está ligado à forma-sujeito que, por sua vez, se constitui pela sua relação com a formação discursiva. A partir desse reconhecimento pode-se levar em conta o chamado "domínio de saber", o da constituição do sentido. 
Assim sendo, podemos concluir que, para esta autora, compreender implica um processo sócio-histórico de construção do sentido, e podemos dizer que há compreensão quando o sujeito reflete sobre os mecanismos de funcionamento do discurso, quando ele reflete sobre os efeitos de sentidos produzidos pelos discursos, considerando, como não poderia deixar de ser, a exterioridade constitutiva dos discursos e não apenas seu espaço significante.

Nesta perspectiva, Orlandi (1993, p.116) atribui ao intérprete a formulação da repetição, isto é, o sujeito reproduz o sentido do texto como se houvesse relação direta entre o texto e seu significado. "Para chegar à compreensão não basta interpretar, é preciso ir ao contexto de situação (imediato e histórico)".

Face a essa discussão, deduz-se que, para a autora, a interpretação não atinge a compreensão, visto que, ao assumir a posição de intérprete, o sujeito ainda não historicizou os sentidos.

Porém, em outro texto, Orlandi (1996, p.18) trata da questão da interpretação relacionada à História, quando diz que "O gesto de interpretação se dá porque o espaço simbólico é marcado pela incompletude, pela relação com o silêncio. A interpretação é o vestígio do possível. É o lugar próprio da ideologia e é "materializada" pela história".

A análise desses dois textos de Orlandi (1993 e 1996) nos confirma quão delicada é a relação do sujeito com a interpretação, visto que a própria autora oscila quando trabalha com o conceito de interpretação, sendo que na obra de 1996 define como "interpretação" aquilo que chamara de "compreensão" em 1993.

Diante disso, entendemos que ainda não está muito bem estabelecida na literatura a definição de interpretação, pois se "para chegar à compreensão não basta interpretar, é preciso ir ao contexto de situação" (ORLANDI, 1993), como podemos ter que "Interpretar é compreender, ou seja, explicitar o modo como um objeto simbólico produz sentidos, o que resulta em saber que o sentido sempre pode ser outro" (ORLANDI, 1996, p. 64)? Podemos pensar que esses são os pontos por onde a interpretação "escapa" ao sujeito, mesmo ao analista de discurso...

Talvez na primeira obra (1993), a autora tenha reduzido o conceito de interpretação, limitando-o ao intradiscurso ("interpretar é 
atribuir sentido levando em conta o contexto lingüístico") e, na segunda obra (1996), a autora amplia tal conceito, relacionando-o ao interdiscurso, ao considerar a história e a ideologia constitutivas do processo de interpretação.

Pretendemos aqui retomar esse "furo" que, a nosso ver, existe na teoria brasileira da $\mathrm{AD}$ sobre o que seja interpretar, e fazer uma proposta no sentido de tamponá-lo. Para tanto, inicialmente defendemos que a relação do sujeito com a construção do sentido deve ser entendida a partir das duas possibilidades de interpretação apontadas no início deste texto, isto é, a interpretação linguajeira e a interpretação do analista. O que nos interessa, aqui, é a segunda, entendida como atividade de interpretação baseada em fundamentação teórica, a qual engloba a compreensão numa visão discursiva, o que leva a considerar que interpretar significa compreender como a ideologia interfere na construçāo de sentidos, num dado momento sócio-histórico.

Assim, a interpretação pode ser entendida como a possibilidade de o sujeito compreender que o sentido pode ser outro, mas não qualquer um, pois existe uma superfície linguíistica que tenta controlar os pontos de fuga, os sentidos que não devem aparecer, mas que aparecem como indícios para aqueles que levam em consideração o funcionamento discursivo, que aceitam que interpretar não é repetir o que está dito, mas sim, estabelecer uma relaçāo entre o dito e a memória do dizer (interdiscurso), que enfim, interpretar é compreender que a ideologia faz parecer naturais determinados sentidos e não outros, e, fundamentados nisso, são capazes de estranhar, investigar, analisar, interpretar, enfim.

Mas nem todos podem compreender o processo ideológico de construção da significação, pois sabemos que sempre há uma interdição a determinados sentidos e, por isso, cria-se o efeito de sentido de que é necessário aprender a repetir o repetível (os sentidos permitidos), tarefa esta que a escola insiste em "repetir", "ensinando" o aluno a interpretar "com clareza" (na acepção do código) o sentido do texto (no singular, paráfrase). A função ideológica da escola, como tem sido dito, é fazer com que todos atribuam o sentido legitimado aos textos aí trabalhados.

A seguir, trataremos das possibilidades de construção dos sentidos, da paráfrase (a repetição do sentido) e da polissemia (o 
múltiplo, o diferente) e como estes pólos estão, para nós, relacionados àquilo que denominamos de fôrma-leitor e de função-leitor.

Paráfrase e polissemia: a construção do sentido na tensão entre o repetível e o "diferente"

Falar em interpretação é falar em sentido, é falar da delicada relação do homem com o processo de significação, não esquecendo que tal relação só é possível pelo discurso.

Pelo fato de não ser algo observável, palpável, prédeterminado, ou, ainda mais forte, controlável, como as ciências positivistas tanto valorizam, trabalhar com esta questão pode ser considerado um tanto quanto enigmático, pois o sentido não está pronto, fechado, não pode ser capturado e, por mais que se tente fazer isso, podemos dizer que não é possível. O máximo que aqueles que pretendem controlar os sentidos (como as instituições escolares, religiosas, governamentais) podem conseguir é eleger um sentido dominante e tentar inculcá-lo nos sujeitos dominados.

Entretanto, por maiores que sejam os esforços dessa tentativa de controle dos sentidos, estes sempre transbordam, escapam, aparecem de outra maneira e essa tensão acaba gerando possibilidades diferentes de leituras, que Orlandi (1993) chama de leitura parafrástica e de leitura polissêmica.

Assim, o discurso torna-se o palco de conflitos entre o institucionalizado e o "diferente", aquilo que foge do sentido dominante e, portanto, deve ser controlado, dominado, até tornar-se a repetição do sentido legitimado pelas instituições.

Pacífico (1996, p.38) compartilha esse ponto de vista:

A leitura acontece dentro de um processo histórico, que também é ideológico, vinculado a determinadas instituições sociais que orientarão a direção que a leitura poderá tomar, o que é possívei porque os leitores, de uma forma ou de outra, também estão vinculados às instituições e já "aprenderam" como devem interpretar os sentidos, que não são "livres", mas produzidos dentro das regras de determinadas formações ideológicas .

Atualmente, porém, questionamos alguns dos pontos colocados na citação acima, pois hoje entendemos que as instituições 
não "orientam" a leitura que deve ser realizada, mas sim, a determinam; além disso, nosso trabalho como docente nos mostra que os leitores, muitas vezes, não "aprenderam como devem interpretar os sentidos" (talvez porque não seja possível aprender isso), e este é um ponto crucial para a escola.

Sendo assim, há uma luta de vozes, em que a dominante tenta abafar a dominada, o que gera a tensão entre a paráfrase (o repetível) e a polissemia (o diferente).

Constatamos que a sociedade (e, é claro, as suas instituições) tem horror ao "diferente" e tenta extirpá-lo, seja por meio de discursos autoritários, seja ideologicamente, fazendo parecer "natural" a ilusão de homogeneização dos sentidos.

Segundo Assolini (1999, p.31), “O processo parafrástico de linguagem encontra na instituição escolar um espaço fértil para concretizar-se e perpetuar-se. Queremos dizer com isso que a instituição escolar dificilmente consegue ouvir sentidos estranhos aos seus".

Diante dessas considerações, é possível entender por que para a maioria dos sujeitos a leitura restringe-se ao intradiscurso, pois os leitores enquanto sujeitos não-analistas, lêem os textos sem considerar todo o processo sócio-histórico (interdiscurso) envolvido na construção dos sentidos, sendo que essa é a leitura que atingiria a interpretação, no sentido que estamos dando ao termo aqui.

Entendemos que, na visão institucional, compreender o sentido é compreender o comum, o invariante, como se só isso fosse possível para o sujeito. Na concepção do discurso escolar, isso pode ser possível, uma vez que ele "apaga" as diferenças existentes entre os sujeitos, e não considera que, de acordo com o contexto sóciohistórico e com a posição de classe, haverá formações ideológicas diferentes que determinarão como os sentidos podem e devem ser produzidos e interpretados.

Sobre essa questão, Pêcheux (1995, p.290) propõe uma concepção de "paráfrase histórico-discursiva para marcar a inscrição necessária dos funcionamentos parafrásticos em uma formação discursiva historicamente dada". Esta proposta pode facilitar o entendimento de como se dá a compreensão e produção dos sentidos. 
Vejamos: todo processo de construção dos sentidos acontece, como dissemos, na tensão entre paráfrase e polissemia, mas na verdade, sempre haverá uma formação ideológica dominante para cada sujeito, e é mediante tal formação que se dá a relação do sujeito com o sentido. Assim, as formações ideológicas dominantes em cada formação social não são as mesmas, e muito menos coincidentes com a ideologia da classe dominante, que é a "evidente", e isto faz com que haja a possibilidade de inúmeros sentidos para os textos.

Dito isso, julgamos que quando os sujeitos constroem sentidos "dentro" de uma mesma formação social, os sentidos são parafrásticos (o sentido repetível constitui os sujeitos inseridos numa formação social dada); porém, quando o sentido é disputado entre formações sociais diferentes, temos que a paráfrase deixa de ser sinonímica (como a escola espera dos sujeitos), e neste momento constroem-se paráfrases histórico-discursivas (como explica Pêcheux, op.cit.), paráfrases estas marcadas pelo fato de as ideologias serem diferentes, e a relação do sujeito com o sentido, também.

A polissemia, no entanto, não é determinada por esta ou aquela formação social, mas sim, é um sentido que se inscreve num determinado momento sócio-histórico.

Considerando todos esses pontos, propomos, então, que existem lugares de sujeito-leitor que assumem o que chamamos de fôrma-leitor (no sentido de fôrma, molde), fôrma esta determinada pela ideologia dominante em cada formação social, que tem como objetivo limitar o processo de significação do sujeito, sua possibilidade de interpretação; por isso, o sujeito-leitor que assume a fôrma-leitor realiza uma leitura parafrástica em que o controle do sentido sempre está presente.

Entendemos, também, que a fôrma-leitor está relacionada à interdição do sujeito ao interdiscurso, o que equivale a dizer que há um corte, uma perda de memória discursiva e o sujeito leitor não consegue inserir-se no processo sócio-histórico de construção de sentidos e, por isso, ele tem a ilusão de que cada palavra tem um significado: o leitor só considera o intradiscurso e assume, desse modo, o que chamamos de fôrma-leitor.

Por outro lado, existem analistas do discurso, isto é, sujeitos que assumem a função-leitor e estes sujeitos não são "formatados" (expressão emprestada da informática para realçar a presença da 
polissemia nos textos), não repetem os sentidos instituídos como dominantes e, sim, procuram compreender como são criados alguns efeitos de sentido e não outros, procuram investigar como se dá, num dado momento sócio-histórico, o funcionamento discursivo, que é novo e único em cada texto; assim, o sujeito que assume a funçãoleitor realiza uma leitura guiada pela interpretação; portanto, polissêmica.

Assim sendo, nossa proposta é que a escola deixe de trabalhar (impor) a fôrma-leitor e crie as condições para o sujeito assumir a função-leitor.

A seguir, discutiremos a noção de esquecimentos, formulada por Pêcheux, mostrando que, para nós, a relação do sujeito com o sentido ou, em outras palavras, a possibilidade de assumir a fôrmaleitor ou a função-leitor, está relacionada a eles.

\section{O sujeito e os dois esquecimentos}

Como vimos dizendo, os sentidos dos discursos que circulam na sociedade são avalizados por determinadas formações sociais (que os materializam nas formações discursivas) e não por outras, o que acontece pelo imaginário, pelo ideológico. A ideologia, por ser inconsciente, limita a pretensa liberdade do sujeito, pois este imaginase "livre" para dizer o que quer, não percebendo que é capturado pela ideologia. Isso faz com que o sujeito não tenha consciência de que não é "dono do seu dizer" e, assim, repete discursos sem questionar os efeitos de sentido produzidos. Por isso, talvez, seja mais fácil levar o sujeito a leituras parafrásticas do que a polissêmicas.

Pêcheux (1993) explica essa questão por aquilo que ele chama de ilusões ou esquecimentos do sujeito. Para o autor, o sujeito está preso às duas ilusões, isto é, à ilusão $\mathrm{n}^{\circ} 1$, que é um ocultamento ideológico, um apagamento para o sujeito do processo pelo qual uma seqüência discursiva concreta é produzida ou reconhecida como tendo sentido, o que faz o sujeito achar que é a origem do seu dizer, que o sentido do seu discurso "nasce" nele. Por esta ilusão, o sujeito não reconhece a inclusão daquilo que ele diz em determinada formação discursiva e não em outra. A ilusão $\mathrm{n}^{\circ} 1$ é da ordem do inconsciente. Quanto à ilusão $n^{\circ} 2$, esta faz o sujeito acreditar que aquilo que ele diz corresponde ao que ele pensa (transparência do pensamento), como se existisse relação entre a palavra e o mundo. É um ocultamento 
lingüístico (pré-consciente/consciente), que está relacionado à seleção de palavras e da forma como colocá-las em discurso (paráfrase), isto é, escolher uma maneira entre as várias possíveis de se dizer a mesma coisa. No entanto, o que não foi enunciado continua a existir, e pode ser acessível ao sujeito, que fez a opção por determinado dizer a fim de induzir o interlocutor a entender de um modo e não de outro.

Não podemos escamotear o fato de que o analista do discurso também é capturado por estes dois esquecimentos, porém, na medida em que ocupa a posição de analista, é possível dizer que ocorrem alguns deslocamentos nestas ilusões, o que lhe permite, segundo Pêcheux (1969) a partir da "dessuperficialização" das marcas encontradas, duvidar da transparência da linguagem, isto é, de que aquilo que foi dito só poderia ser dito daquela maneira e não de outra, e remeter os discursos às suas condições de produção específicas.

Pêcheux (1993, p. 177) diz:

A oposição entre os dois tipos de esquecimento tem relação com a oposição já mencionada entre a situação empírica concreta na qual se encontra o sujeito, marcada pelo caráter da identificação imaginária onde o outro é um outro eu ("outro" com o minúsculo), e o processo de interpelação-assujeitamento do sujeito, que se refere ao que J. Lacan designa metaforicamente pelo "Outro" com $\mathrm{O}$ maiúsculo.

Pois bem, se o processo de assujeitamento se dá de maneira inconsciente, é válido afirmar que o sujeito inserido na instituição escolar (em toda instituição, mas a delimitação se faz necessária para fins metodológicos) não tem consciência de que é interpelado pela ideologia (ilusão $\mathrm{n}^{\circ} 1$ ) e, portanto, não percebe que sua leitura está submetida ao sentido legitimado pela escola; portanto, o papel da escola é levar o sujeito (aliás esta é a expressão usada nos objetivos gerais e específicos que constam do planejamento escolar) a assumir a fôrma-leitor sem questionar tal situação, pois como já dissemos, a ideologia faz com que isso pareça natural.

Desse modo, podemos dizer que a ilusão $\mathrm{n}^{\circ} 1$ interfere na construção da fôrma-leitor, fazendo com o que o leitor acredite que "doou", atribuiu o "seu" sentido, a "sua" interpretação.

Para nós, o fato de o sujeito estar na ilusão $n^{\circ} 1$ torna-se um mecanismo facilitador da tarefa escolar (e institucional, em sentido 
amplo) de "padronizar" sujeitos e sentidos, pois a formação discursiva (FD) dominante, na instituição, (discurso do Outro, inconsciente) leva o sujeito a inscrever-se nela, ler e ser lido por ela, sem questioná-la, como se esta FD representasse aquilo que ele pensa (ilusão $n^{\circ} 2$ ).

Considerando que a escola também trabalha com a "transparência da linguagem", ela não concebe que os sujeitos não possam "compreender" (no sentido criticado acima) a "mensagem" do texto; o que o autor " quer dizer" ; qual é o " sentido imanente" do texto, pois a leitura proposta pela escola supõe uma relação termo-atermo entre linguagem e mundo, ou seja, a escola faz uma análise conteudística dos textos, como se o sentido (no singular) de cada texto fosse transparente para o leitor, algo óbvio de se "compreender".

No entanto, o conflito começa quando o sujeito, que está igualmente na ilusão da transparência da linguagem (e, pelo fato de pertencer a outra FD, a "transparência" não é a mesma- evidência de que os sentidos não são transparentes), não "entende" de acordo com os sentidos determinados pelo discurso pedagógico e produz paráfrases discordantes do esperado pela escola, saindo, portanto, da fôrma-leitor.

Assim, podemos entender que o movimento do sujeito que assume a fôrma-leitor é limitado, visto que este sujeito tem dificuldade de migrar de uma formação discursiva para outra, o que não acontece com o sujeito que assume a função-leitor, pois este busca compreender os processos de construção dos sentidos e duvida da transparência da linguagem.

A função-leitor permite ao sujeito estranhar o óbvio, investigar por que determinado enunciado foi produzido de uma forma e não de outra, aquilo que fica oculto quando um enunciador $\operatorname{diz} A$ e não $B$.

Além disso, conforme discutimos, os discursos também são construídos por conteúdos implícitos e a função-leitor pretende investigar quais sentidos não foram explicitados mas estão significando, pois retomando e confirmando o que temos dito, a função-leitor não se prende ao sentido único, mas procura os pontos em que os sentidos transbordam.

E é em relação ao movimento do sujeito que entendemos a fôrma-leitor e a função-leitor, sendo que esta supõe que o sentido é 
construído a partir de movimentos (função - funcionamento movimento), pois há um continuum, um movimento (sócio-histórico) significativo responsável pela produção dos sentidos. Por outro lado, a fôrma-leitor não inclui tal movimento, e procura um sentido estático e limitado ao texto, caracterizando, realmente, a metáfora da fôrma.

Pêcheux (1995), retomando a expressão introduzida por Althusser, fala sobre a forma-sujeito que é a forma de existência histórica de qualquer indivíduo, agente das práticas sociais. Para o autor, existe uma articulação entre ideologia e inconsciente na constituição do sujeito.

Pêcheux traz este conceito para o discurso e mostra que no discurso isto se dá pela interpelação do indivíduo em sujeito de seu discurso, o que acontece devido a sua identificação com a formação discursiva que o domina, de tal forma que o sujeito re-inscreve o interdiscurso (o já-lá) no "seu próprio" discurso, assumindo a formasujeito. Deste modo, é no interior de uma formação discursiva que se dá o assujeitamento.

Assim, sob a aparência de autonomia, a forma-sujeito dissimula o assujeitamento do sujeito. Ainda para Pêcheux (op.cit.), o sujeito é sempre-já sujeito e isto é possível porque mesmo antes de seu nascimento já existe um interdiscurso que sustenta a constituição deste sujeito. Portanto, para este autor, o sujeito é produzido pela sequiência discursiva, pelo pré-construído.

Pretendemos mostrar aqui que a fôrma-leitor tal como a concebemos, não corresponde à noção de forma-sujeito defendida por Pêcheux, visto que a forma-sujeito é constitutiva do sujeito e este se identifica com ela, através da formação discursiva que o domina, enquanto a forma-leitor não é constitutiva do sujeito, mas é uma das posições que o sujeito pode (deve) assumir em suas práticas de linguagem. Posição esta, conforme estamos mostrando, determinada pela instituição dominante e que procura apagar as diferenças existentes entre os sujeitos.

Por outro lado, a forma-sujeito pode incluir a função-leitor, e questionar os efeitos de persuasão e manipulação produzidos por esses discursos que pretendem criar o efeito de universalidade do sujeito e homogeneidade do sentido. 
Observamos que o sujeito que assume a fôrma-leitor na instituição escolar muitas vezes não se identifica com a formação discursiva dominante nesta instituição, mas é levado a reproduzi-la intradiscursivamente por questões ideológicas (e de poder) conforme já discutimos. Desse modo, enquanto a forma-sujeito dissimula o assujeitamento do sujeito, a fôrma-leitor é a marcação explícita de tal assujeitamento por uma relação desigual de poder.

Para ilustrar este ponto, analisaremos, a seguir, algumas redações de alunos do primeiro ano de Psicologia, de uma universidade particular de Ribeirão Preto - SP, (cf. Pacífico, 2002) redações estas que foram escritas dentro das seguintes condições de produção:

Em sala de aula, foram realizadas a leitura e a discussão do texto As crianças trabalhadoras, de Eugênio Bucci (ver anexo). Após a discussão do texto com os alunos, foi pedido que eles produzissem, como trabalho extra-classe, um texto argumentativo, defendendo seus pontos de vista sobre os temas abordados no texto em questão. Nos recortes abaixo, podemos observar se os alunos assumem a fôrmaleitor ou a função-leitor, e ao mesmo tempo analisar como estes sujeitos trabalham com a construção de sentido(s) :

Recorte 1:

No mundo hoje a criança não vem sendo usada, como o que diríamos, "o futuro da nação" , mas sim, para sustentar interesse bastante econômico da nação.

A criança conhece muito cedo o trabalho, deixando de lado o que realmente lhe é de direito, a escola, a diversão, e a " liberdade". Levando assim, ela a um futuro promíscuo, que tanto ela quanto a nação reflitam um progresso.

O que nos chama a atenção, neste recorte, é a relação que o sujeito estabelece entre "a criança não vem sendo usada" e o "futuro da nação". Quais os efeitos de sentido que isso cria? O leitor poderia interpretar como uma das possibilidades de leitura que a criança deve "ser usada" de acordo com os interesses da nação? Temos, aqui, o sentido (natural/ideológico) da submissão do sujeito aos padrões da nação? Qual é a formação discursiva que relaciona o futuro da criança ao futuro da nação e não ao futuro da própria criança?

Para nós, o sujeito que produziu este texto assumiu a fôrmaleitor, pois percebemos no intradiscurso "marcas" estereotipadas de 
um interdiscurso que sustenta a FD dominante, isto é, a constituição do sujeito como um sujeito da "nação", apagando-se as diferenças e o direito à singularidade.

Além disso, interessante observar que, no recorte, o sujeito parece crer que antes, a criança era usada como o "futuro da nação", mas, hoje, não é, o que está indiciado pelo uso do advérbio "hoje".

Já, no texto de Bucci, que igualmente emprega o verbo usar em "Atualmente, o uso de meninos e meninas na TV faz o contrário: desperta (e instrumentaliza) o consumismo nas crianças para inebriar os adultos", há, também, um conteúdo implícito, mas que constrói um outro sentido, que entra em confronto com o do recorte analisado, pois, em Bucci, fica implícito que, antes, as crianças não eram usadas para despertar o consumismo nas próprias crianças e inebriar os adultos, e hoje ("atualmente") são.

Percebe-se que, no texto de Bucci, o conteúdo implícito denuncia uma situação que está fora da ordem nos dias de hoje, ou seja, o uso de crianças com a finalidade de estimular o consumismo. Seguindo esta análise, podemos dizer que o sujeito da redação representada pelo recorte 1 , fala a partir de uma posição discursiva que não é aquela representante da ideologia dominante que atua no texto de Bucci. Ao contrário, o sujeito produz um discurso antagônico em relação a ela.

Por outro lado, no recorte analisado, o conteúdo implícito sugere que o sujeito fala, no início de seu discurso, de uma posição discursiva que confirma a ideologia dominante, conforme comentamos acima, ao relacionar a criança com o "futuro da nação".

Porém, há uma ruptura nesse sentido, e o sujeito parece estranhar os sentidos dominantes e começa a duvidar deles, o que é indicado pelo uso das aspas nas palavras "futuro da nação" e "liberdade". Estes indícios apontam para a direção de que o sujeito não sabe se pode ou não usar a palavra "liberdade" e o que isso significa, assim, como parece duvidar da expressão "futuro da nação".

Podemos interpretar que o uso das aspas indica, aqui, a referência a um outro discurso (cf. Authier-Revuz, 1998). Ou seja, as aspas parecem marcar a inserção de um discurso outro naquele que o sujeito estava produzindo e, portanto, ele estranha os sentidos que este outro discurso constrói. 
Vejamos outro recorte:

Recorte 2:

As crianças são usadas para vender produtos para os adultos. Os publicitários já descobriram que eles pesam na escolha dos pais, que buscam sua admiração.

No texto de Bucci, temos: "Sim, os publicitários já sabem disso há tempos: crianças pesam, e muito, na decisão de compra dos adultos. Pais compram carros e outras mercadorias na esperança de comprar junto a admiração do filho".

Como podemos notar, o sujeito repete as palavras usadas por Bucci e tenta, com as mesmas palavras, construir seu discurso, mas isso é feito de uma forma desordenada, parecendo uma colagem de enunciados, como se o sujeito extraísse do texto lido aquilo que ele pode ter considerado os "pontos principais" e, com estes, tenta produzir seu texto, o que levou a uma quebra na construção do sentido, como percebemos no final do recorte, em que o sujeito usou a mesma palavra de Bucci, "admiração", e a inseriu em outro enunciado, mas não controlou a dispersão, como pode ser observado em "que buscam sua admiração".

O leitor pode perguntar: admiração de quem? Dos pais, dos publicitários, das próprias crianças?

Mais uma vez, podemos dizer que há várias possibilidades de interpretação, porque o sujeito não controlou o sentido do texto, logo, não assumiu a função-leitor.

Para nós, o fato de o sujeito cursar a universidade e construir seu texto repetindo o ponto de vista de um outro (leitura parafrástica) sobre um tema que julgamos simples de ser tratado, nos faz, mais uma vez, pensar que isto está ligado às tarefas escolares, que tanto valorizam a repetição, a paráfrase que, como vimos, não coloca em disputa o sentido, não estabelece um confronto com sentidos autorizados por outra formação discursiva. Por tudo isso, o sujeito não consegue migrar para outra região do sentido e arrisca-se a construir sentidos que não sejam aqueles produzidos (e legitimados) por alguém.

Podemos entender o porquê de estarmos sempre encontrando esse retorno ao discurso do outro, pois, a nosso ver, essa relação com a alteridade é marcada pela legitimidade do outro em detrimento do 
discurso produzido pelo sujeito, relação esta que, para nós, foi estabelecida pela escola, através das leituras do livro didático, que levam, como já dissemos, o sujeito a assumir a fôrma-leitor e, não, a função-leitor.

Neste artigo, discutimos como a construção de sentido(s) pode estar relacionada à repetição do mesmo (fôrma-leitor) ou às possibilidades de realizar uma leitura sócio-histórica, atribuir vários sentidos para o texto(função-leitor), sendo que esta, para nós, seria a atividade de interpretação.

Diante das análises apresentadas, consideramos que os sujeitos não realizaram a interpretação dos textos lidos em classe, pois não fizeram uma leitura sócio-histórica, como também não historicizaram os sentidos produzidos. Na verdade, percebemos que houve uma repetição formal em relação ao texto lido, o que confirma a fôrma-leitor.

Insistimos em que há necessidade de um trabalho realizado pela/na instituição escolar que permita ao sujeito estar em contato e em confronto com várias possibilidades de leitura, que o trabalho escolar aconteça não pela imposição de um sentido, mas pelo confronto estabelecido entre os sentidos possíveis.

\section{Referências}

ASSOLINI, F.E.P. Pedagogia da leitura parafrástica. Dissertação de mestrado. USP: Ribeirão Preto, 1999.

AUTHIER-REVUZ, J. Palavras incertas: as não-coincidências do dizer. Trad. Claudia Pfeiffer et alli. Campinas: Ed. da Unicamp, 1998.

DUCROT, O. Princípios de Semântica Lingüística. São Paulo: Cultrix, 1972.

HALLIDAY, M. A . K. Cohesion in english. Londres: Longman, 1976.

MAINGUENEAU, D. Novas tendências em análise do discurso. 2.ed. Campinas: Pontes, 1993.

ORLANDI, E.P. Discurso e leitura. São Paulo: Cortez; Campinas: Ed. da Unicamp, 1993. 
DA FÔRMA-LEITOR Ȧ FUNÇĀO-LEITOR

ORLANDI, E.P. Interpretação; autoria, leitura e efeitos do trabalho simbólico. Petrópolis: Vozes, 1996.

PACÍFICO, S.M.R. Os fios significativos da história: leitura $e$ intertextualidade. Dissertação de mestrado. UNESP: Araraquara, 1996.

PACÍFICO, S.M.R. Argumentação e autoria: o silenciamento do dizer. Tese de doutorado. USP: Ribeirão Preto, 2002.

PÊCHEUX, M. Analyse automatique du discours. Paris: Dunod, 1969.

PÊCHEUX, M. Por uma análise automática do discurso: uma introdução à obra de Michel Pêcheux. In: GADET, F. e HAK, T. (Org.). Campinas: Ed. da Unicamp, 1993.

PÊCHEUX, M. Semântica e discurso: uma crítica à afirmação do óbvio. Trad. Eni Orlandi et alli. Campinas: Ed. da Unicamp, 1995.

TFOUNI, L.V. E não tem linhas tua palma: esquecer para poder lembrar. In: ORGANON (no prelo).

\section{Anexo}

BUCCI, Eugênio. As crianças trabalhadoras. Revista Veja. São Paulo, , n. 26, mar.1997.

A mão-de-obra infantil na TV cresce a cada dia, o que, parece, não incomoda ninguém. Embora já existam na opinião pública sinais de recusa à exploração do trabalho de crianças nas olarias, nas carvoarias ou na agricultura, a participação de atores mirins em propagandas, assim como nas novelas e nos filmes, não é encarada como trabalho. É como se fosse uma premiação. Qualquer mãe ficaria orgulhosa de ter o seu filhinho fazendo papel de mamífero numa campanha de leite. Ela dificilmente entenderia a coisa como um tipo de exploração injusta. Para o senso comum, estar na televisão é participar do estrelato, e no estrelato, acredita-se, não há relações trabalhistas.

O fato é que o público aceita e aplaude os programas e as propagandas estrelados por crianças. Como essa que acaba de entrar no ar, de um automóvel. Um grupo de garotos em idade 
de freqüentar o jardim-de-infância troca suas impressões sobre os carros dos pais. O do meu pai é alemão, anuncia um, o do meu pai é japonês, emenda outro, e cada um vai contando sua vantagem. No final, um deles garante que o carro do pai reúne todas as nacionalidades, pois é um modelo mundial e, portanto, melhor que todos os outros. O automóvel surge na cena e todos os coleguinhas ficam embasbacados.

Mas então quer dizer que alunos de jardim-de-infância funcionam para vender até produtos para consumidores adultos? Sim, os publicitários já sabem disso há tempos; crianças pesam, e muito, na decisão de compra dos adultos. Pais compram carros e outras mercadorias na esperança de comprar junto a admiração do filho. Quanto aos filhos, motivados pela TV, repercutem a propaganda dentro de casa: "Compra, paiê!".

É muito gracioso, espontâneo e bem dirigicio o elenco da campanha do tal carro. Da mesma forma, são encantadores os protagonistas mirins dos comerciais de margarina, de sabão em pó, até de brinquedo. E provavelmente a aparição episódica em propagandas como essas não seja prejudicial à criança. Proibi-la seria uma violência absurda. Mas o telespectador e a sociedade não devem esquecer que se trata de um trabalho, que deve ser tratado e regulado enquanto tal. Enxergar esse tipo de trabalho com um pouco menos de glamour contribuiria bastante para atenuar essa consentida mercantilização da infância.

O maior poeta brasileiro sonhou com uma canção que pudesse acordar os homens e adormecer as crianças. Atualmente, o uso de meninos e meninas na TV faz o contrário: desperta (e instrumentaliza) o consumismo nas crianças para inebriar os adultos. 